May 2020

\title{
Review of The Librarian's Guide to Homelessness: An Empathy- Driven Approach to Solving Problems, Preventing Conflicts, and Serving Everyone
}

Sagan Wallace

Oregon State University, sagan.wallace@oregonstate.edu

Follow this and additional works at: https://scholarworks.sjsu.edu/ischoolsrj

Part of the Information Literacy Commons, Scholarly Communication Commons, and the Scholarly Publishing Commons

\section{Acknowledgements}

I would like to thank my colleagues at the Oregon State University Libraries and Press for their support and enthusiasm while I balance my studies and work.

\section{Recommended Citation}

Wallace, S. (2020). Review of The Librarian's Guide to Homelessness: An Empathy-Driven Approach to Solving Problems, Preventing Conflicts, and Serving Everyone. School of Information Student Research Journal, 10(1). https://doi.org/10.31979/2575-2499.100110 Retrieved from https://scholarworks.sjsu.edu/ischoolsrj/vol10/iss1/10

This article is brought to you by the open access Journals at SJSU ScholarWorks. It has been accepted for inclusion in School of Information Student Research Journal by an authorized administrator of SJSU ScholarWorks. For more information, please contact scholarworks@sjsu.edu. 


\title{
Review of The Librarian's Guide to Homelessness: An Empathy-Driven Approach to Solving Problems, Preventing Conflicts, and Serving Everyone
}

\section{Keywords}

empathy-driven librarianship, homeless patrons, information poverty, library management, library policy

\section{Acknowledgements}

I would like to thank my colleagues at the Oregon State University Libraries and Press for their support and enthusiasm while I balance my studies and work.

\begin{abstract}
About Author
Sagan Wallace is the Library Experience and Access Department Evening Supervisor, coordinating projects and facilitate communication between day and night shifts to better serve our patrons. They are the current chair of the Resource Sharing and Fulfillment Team with the Orbis Cascade Alliance. Sagan is in the process of obtaining a Master of Library and Information Science through San Jose State University, and has a bachelor's degree in Chemistry from Concordia University.
\end{abstract}




\section{Dowd, R. J. (2018). The librarian's guide to homelessness: An empathy-driven approach to solving problems, preventing conflicts, and serving everyone. Chicago, IL: ALA Editions.}

Ryan Dowd's 2018 book The Librarian's Guide to Homelessness: An EmpathyDriven Approach to Solving Problems, Preventing Conflicts, and Serving Everyone is an in-depth but readable call to compassion for librarians faced with any sort of public interaction. Librarians report increases in negative encounters with homeless patrons directly or between patrons, frustration over these interactions, and a growing sense of helplessness (Wong, 2009). Some libraries choose to increase security ("Charleston County," 2019), hire social workers (Cathcart, 2008), or change their staffing model and policies to be either more or less restrictive (Collins, Howard, and Miraflor, 2009; Landgraf, 1991).

Much of the literature available for librarians is written from the perspective that homeless patrons are a problem. Dowd's book stands apart from the field in its identification of homeless individuals as valued library patrons rather than nuisances to be dealt with. Dowd draws on his experience as the executive director of a Chicago homeless shelter to give librarians the tools needed to practice "empathy-driven enforcement," a system Dowd claims will reduce problems with homeless patrons by 80 percent (p. xiii).

Dowd begins by refuting a selection of myths about homelessness, such as "most homeless people are unemployed" and "most homeless people have mental illnesses." He then discusses the culture of homeless individuals compared to that of librarians, pointing out that most librarians come from a middle class background, while most homeless patrons come from a poverty class background. When librarians try to enforce middle class mores on a poverty class group of people, conflicts can arise. As the final piece of Dowd's foundation, he discusses the science of empathy, explaining how our need for social acceptance can be used to reduce friction with homeless patrons, or worsen it.

Part Two of Dowd's book puts his foundation into practice. Dowd details a list of practical tools the librarian can use to help enforce compliance with library policies, broken down into Head, Body and Word tools. Head tools are the conceptual shifts a librarian must embrace in order to effectively use the Body and Word tools. Body tools are ways to interact with homeless patrons in a safe and empathetic way. Word tools are ways to speak calmly with your patrons while enforcing library policies - and what not to say.

Finally, Dowd covers examples of how to handle common situations with homeless patrons, including body odor, sleeping in the library and mental illnesses. Each scenario lists the specific steps a librarian can take to respond to the issue, complete with example scripts. While prescriptive, Dowd includes the reasoning behind each step he suggests so the librarian can be fully informed as to why they are responding in this way.

Dowd's book is a solid introduction to a new practice of librarianship. However, a few of his arguments are based on tenuous pop psychology. For example, a Body tool which Dowd titles 'the Marijuana plant' recommends "stand[ing] confidently. The research says that if your posture is confident, your 
mind becomes confident" (p. 90). This 'power pose' psychology, popularized by Amy Cuddy in her 2012 TED Talk, has failed in replication studies (Cesario \& Johnson, 2017). Cesario and Johnson's research indicates that maintaining a power pose can actually be detrimental to the low-status individuals who often receive this advice, as they found no correlation between holding a power pose and succeeding at negotiation tasks. They write,

failing repeatedly when you expect to succeed ... may decrease motivation and increase uncertainty regarding the connection between one's actions and outcomes. Indeed, one might expect this negative outcome to be most likely for low-status individuals, who are more likely to lack the skills needed for success. (Cesario \& Johnson, 2017, p. 787)

In addition, Dowd does not discuss the potential impacts of calling an ambulance. Ambulance rides, where not covered by local taxes, can be overwhelmingly costly, and that burden can fall directly on the homeless patron (Culhane, 2008; Yearwood, 2019). Dowd instructs librarians to call for an ambulance when a patron has a seizure; however, per the CDC this is only necessary in a few cases ("Seizure First Aid", 2019). A simple addition to the book might be to include checking for medical tags, such as the type worn by people diagnosed with epilepsy, before calling an ambulance for a person having a seizure.

Dowd's work is already having an impact on local communities through online and in-person trainings. Despite some potential flaws in the interpretation of psychology research, this is an easily recommended text. It is engaging, wellorganized, and provides librarians with a long list of tools they can use whether they work at a front-line service point or if they are creating library policies. Most importantly, the concept of empathy-driven enforcement can be adapted to serve many vulnerable populations. 


\section{References}

Bardoff, C. (2015). Homelessness and the ethics of information access. The Serials Librarian, 69(3-4), pp. 347-360. doi:10.1080/0361526X.2015.1099590

Cesario, J., \& Johnson, D. J. (2017). Power poseur: Bodily expansiveness does not matter in dyadic interactions. Social Psychological and Personality Science, 9(7), 781-789. https://doiorg.libaccess.sjlibrary.org/10.1177/1948550617725153

Charleston County Public Libraries to add armed guards. (2019, August 13). Count On News 2. Retrieved from https://www.counton2.com/news/latestnews/charleston-county-public-libraries-to-add-armed-guards/

Collins, L. N., Howard, F., \& Miraflor, A. (2009). Addressing the needs of the homeless: A San José Library partnership approach. The Reference Librarian, 50(1), 109-116. https://doiorg.libaccess.sjlibrary.org/10.1080/02763870802546472

Culhane, D. P. (2008). The cost of homelessness: A perspective from the United States. European Journal of Homelessness, 2(1), 97-114. Retrieved from https://repository.upenn.edu/spp_papers/148/

Dowd, R. J. (2018). The librarian's guide to homelessness: An empathy-driven approach to solving problems, preventing conflict, and serving everyone. Chicago, IL: ALA Editions.

Landgraf, M. N. (1991). Library cards for the homeless. American Libraries, 22(10), 946-947, 949. Retrieved from https://www.americanlibrariesmagazine.org

Seizure first aid. (2019, January 10). Centers for Disease Control and Prevention. Retrieved from https://www.cdc.gov/epilepsy/about/first-aid.htm

Wong, Y. L. (2009). Homelessness in public libraries. Journal of Access Services, 6(3), 396-410. https://doiorg.libaccess.sjlibrary.org/10.1080/15367960902908599

Yearwood, L. (2019, March 29). Taken for a ride: How ambulance debt afflicts the extreme poor. The American Prospect. Retrieved from https://prospect.org/ 